\title{
POLITENESS STRATEGIES AND LINGUISTIC POLITENESS MARKERS OF IMPERATIVE IN THE VERY BEST OF DONALD DUCK COMIC SERIES AND THEIR TRANSLATION IN INDONESIAN
}

By:

\author{
Nunun Tri Widarwati \\ Lecturer in Veteran Bangun Nusantara University of Sukoharjo \\ Doctorate Student of Linguistics, Majoring in Translation \\ Postgraduate Program, Sebelas Maret University \\ E-mail: nununtriwidarwati@gmail.com
}

\begin{abstract}
The present study examines politeness strategies and linguistic politeness markers of English imperative speech acts used in The Very Best of Donald Duck Comics Series. It also identifies the translation techniques applied to translate those markers into Indonesian and evaluate their accuracy and acceptability. The findings indicate that three politeness strategies (bald on record, positive politness and negative politeness) are used and about thirty five linguistic politeness markers are identified and translated in Indonesian using five translation techniques (literal, variation, deletion, borrowing and established equivalence). The findings also show that the accuracy and acceptability of the translation of linguistic politeness markers are found to be good. Nevertheless, the application of deletion technique tends to distract the pragmatic meaning and force of the linguistic politeness markers in the target language. In such a case, deletion technique should be avoided.
\end{abstract}

Key words: linguistic politeness stretegies, linguistic politeness markers, translation technique, accuracy, acceptability

\section{INTRODUCTION}

The effetiveness of a given language as a means of communication depends not merely on the clarity of information being conveyed but also on the effect it has on the hearer. It is to the fact that eventhough words uttered are familiar to the hearer, misunderstanding and even the feeling of being offended may occur due to the inappropriate way the words are expressed. Native speakers of Indonesian, for instance, have been familiar with the term of address kamu which refers to the person they talk to. However, they will be judged for being completely impolite if they use it for older persons.

Politeness as a linguistic phenomenon has been discussed and studied widely by scholars within the pragmatics domain. Generally they share the conception that politeness is universal in nature as it can be found in every speech community though ways through which it is realized and manifested may be divergent due to cultural differences. If this is the case, politeness is also a cultural phenomenon. 
Translating as an activity and translation as a result of the activity cannot be separated from the notion of culture. In their attempt to render messages of the source text into the target text, translators are generally faced with complex problems as a result of the system differences and the existance of cultural gap between the two languages. Politeness as a linguistic and cultural phenomenon is problematic in translation activities. In relation to this, Yaqubi, Sharifabad and Rahman (2012: 1) state,

Politeness' is one of the very cultural problematic and elusive notions in translation because of the diversity of factors, linguistic and non-linguistic involved in it. In every culture across the universe, considerate participants use principles in conducting conversation including being generous, tactful and modest, etc., to prevent from being 'impolite'. But different social groups may possess different principles or give priority to some norms of politeness more or less than other groups.

The present study focuces on imperative speech act. It precisely examines linguistic politeness markers of English imperative found in The Very Best of Donald Duck Comics. The study aims to 1) identify the linguistic politeness markers of English imperative, 2) identify translation techniques used to render them into Indonesian, and examine the effect of the translation techniques on the accuracy and acceptability of the translation.

\section{Politeness: Defenition and Concept}

Lakoff (1975) defines politeness as a form of behavior developing in society to reduce frictions in communication. With similar vein, Leech (1983) states that politeness is a form of behavior aimed to develop and maintain mutual interpersonal relationship. Meanwhile, politeness according to Yule (1996: 106) is an interpersonal relationship system designed to facilitate interaction by reducing conflict and friction. Yule (1996: 134) further states that in communication, politeness is a tool to show an awareness of someone's face. The term 'face' here is understood as someone's public self-image and refers to social and emotional sense of self that everyone has and expects everyone to recognize (Brown \& Levinson, 1996: 160).

Brown and Levinson categorize face into two types: positive face and negative face. Positive face refers to the someone's desire desires to be liked, approved of, respected of and appreciated by others and negative face refers to somene's desire to not be impeded or put upon, to have the freedom to act as one chooses (Thomas, 1995:169). Brown and Levinson (1987: 65) argue that certain kinds of acts intrinsically threaten face, namely those acts that by their nature run contrary to the face wants of the hearer and / or of the speaker. This suggests that being polite in interpersonal interaction means preserving both kinds of faces. 
As stated earlier, politeness is a universal and relative concept in the sense that each social group has its own politeness principle. However, one politeness principle may not or even cannot be applied universally in every community group as politeness principle is bound to cultural divergences (Zhang, 2011: 3).

An utterance produced in every speech event has three dimensions. The first dimension is locutionary act, an act of producing a meaningful utterance. The second dimension is illocutinary act, referring to the intention or function of the utterance. The third dimension is perlocutionary act, referring the effect the utterance has on its hearer (Yule, 1996: 83 - 84). Illocutinary act has five general function manifested through declarative, representative, expressive, directive and commissive. Directive, also known as imperative speech act is an act of directing the hearer to do something as intended by the speaker. This includes, for instance, commanding, suggesting, ordering and etc and it can be in the forms of positive, negative and interrogative sentences (Yule, 1996: 93).

A directive or imperative speech act is said to have linguistic and pragmatic politeness dimensions. Linguistic politeness is characterized by the presence of linguistic politeness markers. The most obvious example of a politeness marker in English is please, but there are others, e.g., if you wouldn't/don't mind, tag questions with the modal verb will/would following an imperative structure (Close the door, will you/would you?), etc. In Indonesian, linguistic politeness markers include tolong, mohon, mari, silakan, coba, ayo, biar, harap, hendak(lah/nya) dan sudi kiranya / sudilah kiranya / sudi apalah kiranya in Indonesian (Rahardi, 1999). Meanhile, pragmatic politeness is characterized by declarative and interrogative politeness.

As has been stated previously, politeness as a linguistic and cultural phenomenon creates a complex problem in translation practices as a translator is expected to preserve both the pragmatic meaning and force of a translation. In other words, he or she is expected to produce not only an accurate but also acceptable translation. To achieve this, he or she needs to apply appropriate translation strategies and techniques such as borrowing, calque, literal translation, transposition,modulation, established equivalence and etc (for details description of the those translation technique, see Molina \& Albir, 2002).

\section{RESEARCH METHOD}

This study applies a qualitative approach with content analysis. The data for the study are in the form of linguistic politeness markers of English imperative and their translation in Indonesian collected from a bilingual comic The Very Best of Donald Duck Comic Series. 
Other data are translation techniques used to render those politeness markers and statements about the quality of the translation of the markers in terms of accuracy and acceptability. The translation techniques were identified through comparison of the original linguistic politeness markers with their translation in Indonesia. The accuracy and acceptability of the linguistic politeness markers translation were determined using an instrument proposed by Nababan, Ardiana and Sumardiono (2012). Overall, the research data were analyzed following Spradley's data analysis technique which covers domain analysis, taxonomy analysis, componential analysis and cultural theme analysis (Spradley, 2006).

\section{RESEARCH FINDINGS}

\section{Politeness Strategies in Imperatives}

This study identified 53 imperatives using three politeness strategies: bald on record, positive politeness and negative politeness. Bald on record politeness strategy was found to be the most frequently used (24) followed by positive politeness (18) and negative politeness (11). Bald on strategy was realized through the use of direct and concise utterances without attempting to reduce threats to the face of the hearer as exemplified by the following data:

“Hey, Duck! Get a move on! We aren’t paying you to loaf!" (01)

"Fasten your seatbelts! We're taking off!" (06)

"Show Mr Gearloose the moonbean moderator!" (29)

Positive politeness strategy, on the other hand, attempts to reduce threats to the positive face of the hearer by packaging the utterances in such a way as this strategy also attempts to obtain cooperation from the hearer, as shown by the following data:

"Please, Help! “ (04)

"Well just take a short cut across these fields!" (05)

"Watch out your driving, Duck! " (08)

Negative politeness strategy does not attempt to take into account the negative face of the hearer and this was realized through the utilization of direct formation of utterances, as exemplified below.

"You've got to arrest us!" (11)

"You just have to arrest me! "(18)

"You boys best be carefull!" (19)

\section{Forms of Linguistic Politeness Markers of Imperative}

Linguistic politeness markers refer to linguistic entities whose presence makes the utterance more polite. This study found at least 6 types of markers indicating politeness in imperative. These include the use of please, just and let, and the use of terms of address (you boys, kids), declarative and interrogative utterances. 
The use of please was aimed to soften the intention of the imperative as this marker was understood not merely a command but also a request. This study identified two imperatives using please as their linguistic politeness markers, as shown below.

"Please, Help?" (04)

"Please arrest us" (10)

A similar case also happens to the linguistic politeness marker just attached to the imperative. The use of just was aimed to make the intention of the imperative utterances more polite, as shown below.

"We'll just take a short cut across these fields!" (05)

"Just save us from that crazy Duck!" (12)

"You just have to arrest me!" (18)

"Don't just be late for tomorrow's race!" (26)

"Just want you to cool down a little, ladies!" (43)

"Just name it, Grandma!" (50)

"Just make sure the goat doesn't get my flowering shrush!" (51)

Other linguistic politeness markers are terms of address added to the imperative to make the utterance more polite. Terms of address as indicators of linguistic politeness of imperative were generally used among speakers who know each other well. Their use was found to be applied more frequently compared to other linguistic politeness markers since of 54 imperatives, 14 used terms of address as their linguistic politeness markers, as shown below.

"Watch out your driving, Duck!" (08)

"You boys best be carefull!" (19)

"Come play with us, Donald!" (21)

"Help us, unca Donald!" (24)

"Let's do some sightseeing, kids!" (25)

"So, let's fly out to your exciting project, Mr and Miss Lengrad!" (27)

"Let's fly to Montreal, guys!" (30)

"Look at that getup, Wally!" (32)

"Excuse me, sir, can you help me with my car?" (33)

"Stay here, you lousy spy!" (36)

"Hear me, wicked townspeople!" (37)

"Er....stay here, Mortals!" (38)

"Keep your big beak shut, Glomgold!" (41)

"Just want you to cool down a little, ladies!" (43)

"Find yourself another driver, uncle! " (45)

"Get out of here, you wretch!" (47)

"Don’t forget little Gretchen, Donald!" (49)

"Just name it, Grandma!" (50)

This study also identified two imperatives whose linguistic politeness markers were realized through declarative utterances and one imperative expressed in interrogative form intends to make the utterance more polite, as shown below.

"You've got to be more carefully when clean!" (03) 
"You've got to arrest us!" (11)

"Excuse me, sir, can you help me with my car?" (33)

\section{Translation Techniques}

One of the objectives of the present study is to identify translation techniques used to render the linguistic politeness markers of English imperatives into Indonesian as found in a bilingual comic The Very Best of Donald Duck Comics Series. The data analysis indicates that there are five translation techniques used and the variation technique appears to be dominantly applied followed by established equivalence, deletion, literal and borrowing respectively, as summarized in Table 1.

Tabel 1. Teknik Penerjemahan Penanda Kesantunan Linguistik

\begin{tabular}{|l|l|l|l|}
\hline No & Teknik Penerjemahan & Data & Jumlah \\
\hline 1 & Harfiah & $03,11,36,37,38$ & 5 \\
\hline 2 & Variation & $04,10,19,22,25,27,33,41,43,50,51$ & 11 \\
\hline 3 & Peminjaman & $21,32,49$ & 3 \\
\hline 4 & Pengurangan (reduction) & $12,18,26,35,47$, & 5 \\
\hline 5 & Padanan Mapan & $08,42,45$, & 7 \\
\hline & & Total & 33 \\
\hline
\end{tabular}

\section{Literal Technique}

The application of literal technique is characterized by the adjustment of the word order of the linguistic politeness markers to conform to the grammar of the Indonesian language, as shown below.

"You've got to be more carefully when clean!" (03)

(Kamu harus lebih berhati-hati kalau membersihkan!)

"You've got to arrest us!" (11)

(Kalian harus menangkap kami!)

"Stay here, you lousy spy! "(36)

(Diam di sini, kamu mata-mata payah!)

"Hear me, wicked townspeople!" (37)

(Dengarkan aku, penduduk kota jahat!)

"Stay here, Mortals!" (38)

(Tetap di sini, makhluk hidup!)

\section{Variation}


Variation tecnique is used to translate dialect-related utterences. It is also applied to render formal or informal-related utterances. The linguistic politeness marker please in for instance, can be translated into tolong or mohon to indicate its level of formality.

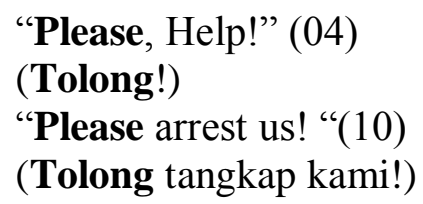

Similarly, the linguistic politeness markers let and just have various equivalence in Indonesian, depending on the situational context of the utterances. As shown below, let was translated into ayo $(22,30)$ and mari $(27)$, and just was rendered into hanya (05) and saja (51) respectively.

"Let's nose around the woodpile!" (22)

(Ayo kita ke tumpukan kayu!)

"So, let's fly out to your exciting project, Mr and Miss Lengrad!" (27)

(Mari kita terbang ke proyekmu yang menarik, Pak dan Nona LeGrand!)

"Let's fly to Montreal, guys!" (30)

(Ayo kita terbang ke Montreal!))

"We'll just take a short cut across these fields!" (05)

(Kita hanya tinggal mengambil jalan pintas melalui ladang ini!)

“Just make sure the goat doesn't get my flowering shrush!"(51)

(Pastikan saja si kambing tidak memakan bungaku!"

A similar case also happens to terms of address used as linguistic politeness markers in imperative utterances where you boys (19) was translated into anak-anak though it can be altered into cah or bocah-bocah.

"You boys best be carefull!" (19)

(Kalian berhati-hatilah, anak-anak!)

"Let's do some sightseeing, kids!" (25)

(Ayo kita jalan-jalan, anak-anak!)

"Just want you to cool down a little, ladies!" (43)

(Cewek-cewek, kalian tenang sedikit, dong!)

"Just name it, Grandma!" (50)

(Sebutkan saja, Nek!)

\section{Borrowing}

There are two types of borrowing technique identifiend in this study. They are pure borrowing and naturalized borrowing, used to translated terms of address in the form of proper nouns. Pure borrowing was applied to render Donald (21), Lengrad (27) and Wally (32) while naturalized borrowing was used to handle Donald (49) which was translated into Donal.

Come play with us, Donald!" (21)

(Ayo bermain dengan kami, Donald!)

"So, let's fly out to your exciting project, Mr and Miss Lengrad!" (27) 
(Mari kita terbang ke proyekmu yang menarik, Pak dan Nona LeGrand!)

"Look at that getup, Wally!" (32)

(Lihat pakaiannya, Wally!)

“Don't forget little Gretchen, Donald! “ (49)

(Jangan lupakan si mungil Gretchen, Donal!)

\section{Deletion}

This technique is realized to the omission of linguistic politeness marker from the the target utterance. In the original imperative utterances, the linguistic politeness markers, such as just $(12,18,26)$, let (35) dan term of adrees you wretch (47) were added to make the intention of the speaker more polite. However, those markers were deleted by the translator.

\footnotetext{
"Just save us from that crazy Duck!" (12)

(Selamatkan kami dari bebek gila itu!)

"You just have to arrest me!" (18)

(Kalian harus menangkap kami!)

"Don't just be late for tomorrow's race!" (26)

(Jangan terlambat untuk lomba besok!)

"Let's hit him on the head!" (35)

(Pukul kepalanya!)

"Get out of here, you wretch!" (47)

(Pergi kau dari sini!)
}

\section{Establish Equivalence}

This technique requires the use of lexical item commonly used in the target language based on daily used. The application of the technqiue can be seen below.

"Watch out your driving, Duck! " (08)

(Perhatikan cara mengemudimu, Bebek!)

"Don't let him provoke you, uncle!" (42)

(Jangan terpancing paman!)

"Find yourself another driver, uncle!" (45)

(Silakan cari pengemudi lain, Paman!)

\section{The Accuracy and Acceptability of the Translation of the Linguistic Politeness Markers}

The accuracy and acceptability of the translation of the linguistic politeness markers were found to be good. Their pragmatic meaning and force are generally maintained in the translation version. Nevertheless, a small number of linguistic politeness markers were deleted. As a result, their translation are automatically inaccurate and unacceptable as well.

\section{IV.DISCUSSION}

Three types of politeness strategies were identified in this study. They are bald on record strategy, positive politeness and negative politeness, used in the original imperatives. 
Their version in Indonesian also uses similar strategies. This validates the hypothesis that politeness is a universal concept that "it occurs in all civilized societies, even though the social norms relating to what is and what is not considered polite behavior may vary across cultures" ( Amani and Ghadim, 2013: 101). In relation to this, Xiujun (2001: 114) states

What is common to these varying conceptualizations is the idea of appropriate language use associated with smooth communication. This smooth communication is achieved on the one hand through the speaker s use of intentional strategies to allow her / his utterances to be received favorably by the addressee and on the other hand by the speaker's expression of the expected and prescribed norms of speech.

While politeness and politeness strategies are inherent in all personal interactions of different social groups, their manifestation and realization through the addition of linguistic politeness markers are different from one another. To take for example, the utterance in English "Could you open the window, please!" is more polite than "Could you open the window!" or "Open the window, please!" which is more polite than "Open the window". The examples indicate that politeness in English can be realized through the use of one or two politeness markers alltogether. To show level of politeness behavior in Indonesian, we may use various utterances, such as "Tolong buka pintu itu!" or "Mohon buka pintu itu!" or "Dapatkah anda membuka pintu itu!" or "Buka pintu itu", but we never say "Mohon dapatkah anda membuka pintu itu".

As a long as translation is concerned, the problem lies not on the absence of politeness and politeness strategies themselves in the target language but on the lack of cross-cultural pragmatic knowledge and competence of the translator. A study by Triki (2013), for instance, reveals that translation students in her study, tend to treat translation at syntactical level and thus focuse not on pragmatic meaning and forces but on literal meanings. Such phenomenon is also identified in this study where some linguistic politeness markers were deleted from the target imperatives. This indicates that the translator is not aware of the importance of those markers as linguistic devices to make unterances more polite.

\section{CONCLUSION AND SUGGESTION}

Based on data analysis, it can be concluded that three types of strategies and at least 53 linguistic markers to show levels of politeness of imperative utterances in the original text. The translator generally maintained those three politeness strategies and linguistic politeness markers in his/her translation by applying five translation techniques (literal, borrowing, deletion, established equivalence and variation). The accuracy and acceptability of the 
translation of the linguistic politeness markers are found to be good though some of them are neitheir accurate nor acceptable due to the use of deletion technique.

The research findings suggest that the translator should treat equivalence not at syntactical but on pragmatic level. He should avoid using deletion technique to translate linguistic politeness markers as the application of the technique will result in the distortion of pragmatic meaning and forces.

\section{REFERENCES}

Amani, B \& Ghadim, Z.N.. (2013). "A comparative study of the implementation of politeness strategies among Iranian EFL learners studying MA in Literature, Translation, and Teaching”. In International Journal of English and Education. Volume:2, Issue:1, January 2013.

Brown, P. \& Levinson, S.C. (1996) Politeness: Some universals in language usage. Cambridge: Cambridge University Press.

Lakoff, R. (1975). Language and women's place. New York: Harper and Row Publishers.

Leech, G. (1983) Principles of pragmatics. London: Longman Group Limited.

Molina, L \& Albir, A.H. (2002) "Translation technique revisited: A dynamic and functionalist approach”. In Journal Meta, Vol. XLVII, No. 4, 499-512.

Nababan, M.R. (2010) “Teknik-teknik penerjemahan teks". A Paper presented in Seminar Nasional Penerjemahan "Teknik Penerjemahan Teks" on June 30, 2010 at Universitas Widya Mandala Madiun.

Nababan, M.R, Ardiana \& Sumardiono (2012) "Pengembangan Model Penilaian Kualitas Terjemahan”. A Report of HIKOM Resarch. Surakarta: Universitas Sebelas Maret.

Rahardi, R.K. "Imperatif dalam bahasa indonesia: Penanda-penanda kesantunan lingustiknya”. In Journal Humaniora No. 11 Mey - August 1999.

Spradley, J. 2006. Metode Etnografi. Yogyakarta: Tiara Wacana. 
Thomas, Jenny. 1995. Meaning in Interaction: an Introduction to Pragmatics. New York: Longman Group Limited.

Triki, M (2013). "A pragmatic approach to the study of English/Arabic translation errors". In Journal Academica, Vol (31), pp. 39 - 51, March 31, 2013.

Xiujun, L. (2001). "A study on linguistic politeness phenomena in English". Unpublished M.A. Thesis, China: Graduate School of Changwon National University.

Yaqubi, Mojde., Sharifabad \& Rahman (2012) "Gender-linked choice of politeness strategies applied to translation of persian cace-threatening acts into English.” In International Journal of Applied Linguistics \& English Literature Vol. 1 No. 7; November 2012.

Yule, G. (1996) Pragmatics. Oxford: Oxford University Press.

Zhang, Tao. (2011) "Politeness principle in the translation of business letters". In Jurnal Theory and Practice in Language Studies, Vol. 1, No. 6, pp. 615-621, June 2011 